\title{
The reuse of abandoned Acquaresi mine voids for storage of the Masua flotation tailings
}

\author{
Pier Paolo Manca $\cdot$ Paolo Desogus · Giampaolo Orrù
}

Received: 2 July 2014/Revised: 2 August 2014/Accepted: 3 August 2014/Published online: 10 October 2014

(C) The Author(s) 2014. This article is published with open access at Springerlink.com

\begin{abstract}
Often in abandoned mine sites are present both underground voids produced by mining and the tailings of treatment plant. An interesting solution for the rehabilitation of the sites would be to place the tailings of the process in the underground mining voids, thus obtaining the reclamation of surface areas and the stabilization of abandoned voids to prevent the dangerous phenomena of subsidence. However, these operations require inert waste, which must not be source of pollution, and the choice of a water/solid optimum to ensure good conditions of pumpability.
\end{abstract}

Keywords Acquaresi mine $\cdot$ Mine voids $\cdot$ Masua $\cdot$ Flotation tailings

\section{Introduction}

The paper refers the results of a research on the characteristics of a mine backfill used for the dual purpose of disposing mining waste pollutants and stabilize the voids of an abandoned mine with subsidence problems. The important parameters in the usual applications (cut and fill mining methods) are the strength and pumpability. In the proposed application, however, the important parameters are the non-pollution of the groundwater and pumping, while the resistance is less important.

The case discussed is the draft environmental recovery of the area Acquaresi-Masua located on the southwestern coast of Sardinia (Italy) where they were held, respectively, the explotation activity of an important mine of lead and zinc and the annex treatment plant (Costa et al. 1998). The mine, exploited by sub level stoping method and without backfills, was home to important phenomena of subsidences that before had led to the closure and then have compromised the surrounding areas. The treatment flotation Masua plant produced tailings that were deposited in

P. P. Manca $(\varangle) \cdot$ P. Desogus · G. Orrù

DICAAR, Department of Civil Engineering, Environmental and

Architecture, University of Cagliari, Cagliari, Italy

e-mail: ppmanca@unica.it two large settling ponds occupying a volume of about $2 \mathrm{Mm}^{3}$, characterized by a polluting capacity.

The rehabilitation of the area can be achieved by resorting to the classical mining backfill (Batchelor 2006). To this end, we studied the use of flotation tailings located in the basins of Masua, suitably inerted and mixed through a process of stabilization and solidification. The tailings of Masua would be pumped through an existing mine tunnel between the plant site and the voids to be filled. However, to achieve such a project will need to not pollution of the groundwater. This may be achieved by filling the voids using a mix geochemical inert, as required by current regulations.

The total cost of backfilling operations is particularly high for the large volume of material involved (Belem and Benzaazoua 2004). However, the unit cost and the environmental interference are certainly the minimum achievable for at least three special features that characterize the solution. A pollutant material is transformed into a filling; the Portland cement first is an inerting agent, than is a binder; all the backfilling operations take place in underground without any environmental interference.

In the clean-up activities to reduce the metal mobility or to make them as possible insoluble, we proceed by adjusting the $\mathrm{pH}$ (Fig. 1) raising it or lowering it depending on the outcome you want to achieve (EPA 1980). 


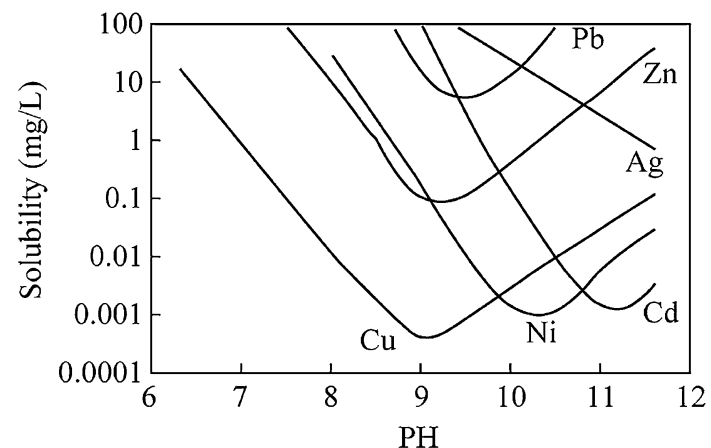

Fig. 1 Diagram of solubility of metal hydroxides as a function of $\mathrm{pH}$ (EPA 1980)

Portland cement is a system with high alkalinity and in certain cases may be a sufficient condition to the treatment of much hazardous waste. However, the final $\mathrm{pH}$ of the system may cause the increase of the solubility of certain heavy metals and therefore are unable to stabilize the metal only with the use of cement.

However, the use of suitable additives in the presence of Portland cement form insoluble compounds with heavy metals, limiting their mobility. In this context, the use of potassium phosphate complex lead, the main contaminant present in eluates, forming pyromorphite $\left(\mathrm{Pb}_{5}\left(\mathrm{PO}_{4}\right)_{3} \mathrm{Cl}\right)$, highly stable in wide $\mathrm{pH}$ ranges (Ruby et al. 1994; Ryan et al. 2001; Scheckel and Ryan 2002, 2004).

\section{The mines}

The Acquaresi mine (see Fig. 2) was active using modern production systems between 1976 and 1998, when it was
Table 1 Main properties of the tailings

Natural water content: $17 \%-24 \%$

Dry density: $1,790 \mathrm{~kg} / \mathrm{m}^{3}$

Void ratio: 0.61

Particle density: $2,750 \mathrm{~kg} / \mathrm{m}^{3}$

Total volume of Masua basins: $2.4 \mathrm{Mm}^{3}$

Mineral composition: calcite, dolomite, quartz, Sphalerite and smithsonite

$\mathrm{Zn}$ in the water leaching: $0.383 \mathrm{mg} / \mathrm{L}$

closed due to reasons of safety after the collapse of the roof (Costa et al. 1998; Grosso and Manca 2009). The extracted material was a mix of lead and zinc sulphides encased in limestone, positioned near the Cabitza shale. The ore body develops along a North-South direction, with sub vertical extension to a depth of about $400 \mathrm{~m}$ and average width of around $50 \mathrm{~m}$

The thickness of the overburden, made up of fractured and faulted limestone, varies between 30 and $180 \mathrm{~m}$.

Two systems of subvertical faults; a main one, in the same $\mathrm{N}-\mathrm{S}$ direction of the orebody and a secondary one running in an E-W direction, cross both the orebody and the country rock. Owing to the good mechanical properties of the limestone, the sub level stoping method was adopted, which produced a total of six large rooms which develop on three levels in a N-S direction, and occupy a total volume of about $2.1 \mathrm{Mm}^{3}$. The mine is connected to the beneficiation plant and tailing dams by a mine tunnel of about $5 \mathrm{~km}$ in length. The underground water level inside the mine is about $+90 \mathrm{~m}$ a.s.l. while the mine develops between +320 and $-90 \mathrm{~m}$ asl. The chemical analyses of the groundwater and the water

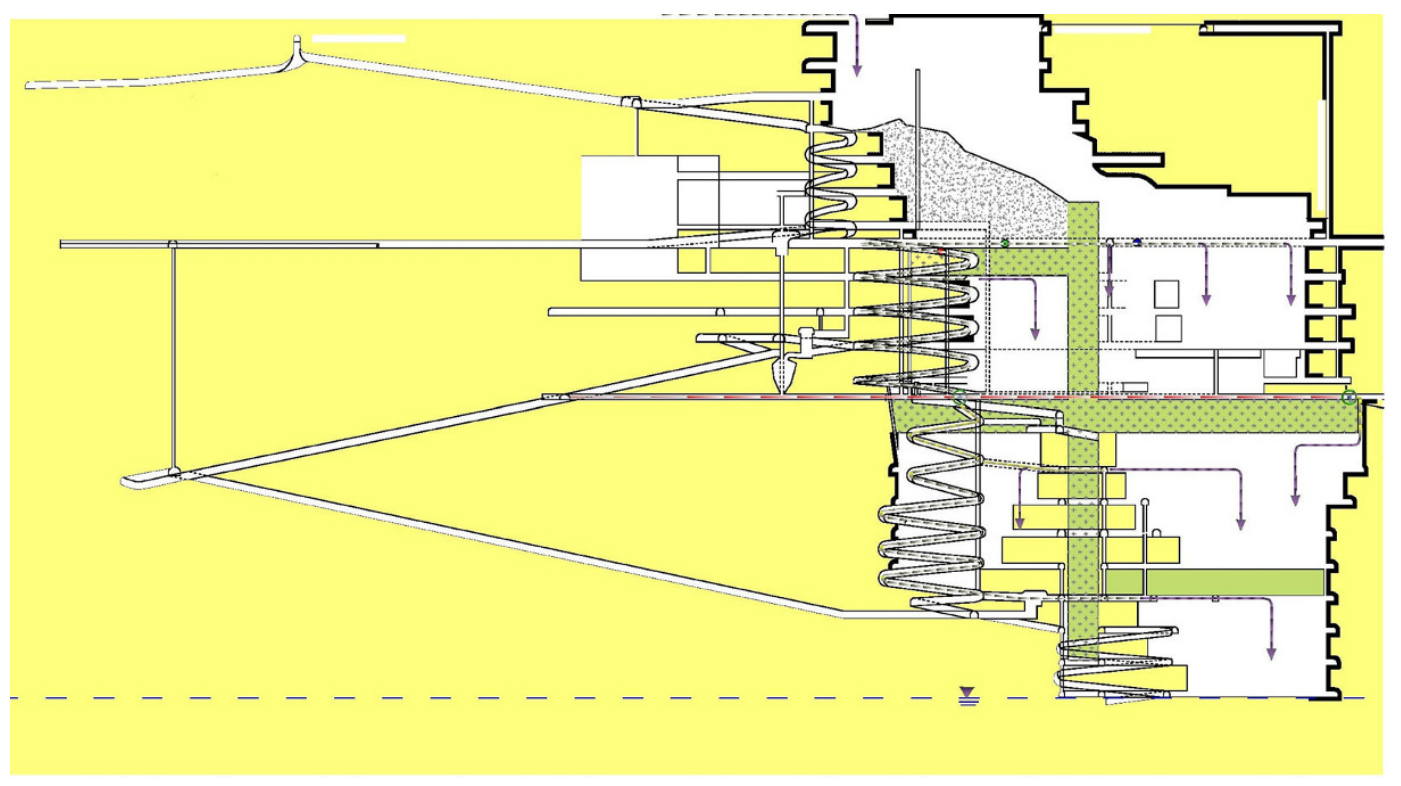

Fig. 2 Vertical section of the Acquaresi mine 
Table 2 Chemical analysis of tailings: major and LOI (\%)

\begin{tabular}{lc}
\hline Parameter & $\%$ \\
\hline $\mathrm{Al}_{2} \mathrm{O}_{3}$ & 0.8 \\
$\mathrm{Fe}_{2} \mathrm{O}_{3}$ & 1.1 \\
$\mathrm{MnO}$ & 0.1 \\
$\mathrm{MgO}$ & 2.1 \\
$\mathrm{CaO}$ & 46.9 \\
$\mathrm{~K}_{2} \mathrm{O}$ & 0.3 \\
$\mathrm{Na}_{2} \mathrm{O}$ & 0.01 \\
$\mathrm{TiO}_{2}$ & 0.04 \\
$\mathrm{P}_{2} \mathrm{O}_{5}$ & 0.05 \\
$\mathrm{SiO}_{2}$ & 6.6 \\
$\mathrm{LOI}$ & 39.2 \\
Total & 97.1 \\
\hline
\end{tabular}

Table 3 Chemical analysis of tailings: TVL (mg/kg)

\begin{tabular}{lrl}
\hline Parameter & TLV & Tailings \\
\hline $\mathrm{pH}$ & 20 & 8.1 \\
$\mathrm{As}$ & 2 & 8.2 \\
$\mathrm{Cd}$ & 150 & 56.2 \\
$\mathrm{Cr}$ & & 7.8 \\
$\mathrm{Cu}$ & 120 & 20 \\
$\mathrm{Fe}$ & & 8,495 \\
$\mathrm{Hg}$ & 1 & 3.1 \\
$\mathrm{Mn}$ & & 976 \\
$\mathrm{Ni}$ & 120 & 4.6 \\
$\mathrm{~Pb}$ & 100 & 2,354 \\
$\mathrm{Sb}$ & 10 & 2 \\
$\mathrm{Se}$ & 3 & 2.6 \\
$\mathrm{Zn}$ & 150 & 7,860 \\
$\mathrm{~S}_{\text {tot }}$ & & 7,990 \\
$\mathrm{Sulfate}$ & & 559 \\
$\mathrm{CN}$ & & $<1$ \\
Fluotale & 1 & 4.6 \\
\hline
\end{tabular}

drained at Masua through the tunnel indicates that the value of $\mathrm{Zn}$ is slightly higher than $1 \mathrm{mg} / \mathrm{L}$.

The mine was affected by subsidence phenomena essentially produced by two distinct mechanisms: the first is that of detachment or the sliding of blocks and affects the limestone, crossed by conjugate fault planes, and the second is that of the landslide, and affects portions of the hangingwalls in shale.

\section{The tailings}

The waste in the tailing basins were produced by the Masua flotation plant from 1968 to 1985 . In 1984 the beneficiation plant processed about $700 \mathrm{kt}$ of raw material made up of
Table 4 Strength and elasticity modulus for cemented sandfill (Thomas et al. 1979)

\begin{tabular}{lllll}
\hline $\begin{array}{l}\text { Cement } \\
\text { content } \\
\left(\mathrm{w}_{\mathrm{t}} \%\right)\end{array}$ & $\begin{array}{l}\text { Curing } \\
\text { time } \\
\text { (days) }\end{array}$ & $\begin{array}{l}\text { Cohesion } \\
(\mathrm{kPa})\end{array}$ & $\begin{array}{l}\text { Internal } \\
\text { friction } \\
\text { angle }\left(^{\circ}\right)\end{array}$ & $\begin{array}{l}\text { Modulus } \\
\text { of elasticity } \\
(\mathrm{MPa})\end{array}$ \\
\hline 4 & 28 & 150 & 30 & $200-400$ \\
8 & 28 & 310 & 33 & \\
16 & 28 & 1,460 & 36 & \\
\hline
\end{tabular}

Table 5 Classical mix composition of tailings cemented backfill (Fall \& Benzaazoua 2003)

\begin{tabular}{lll}
\hline Ratio by weight $\mathrm{w}_{\mathrm{t}}$ & Symbols & Values \\
\hline Binder/aggregate & $\mathrm{B} / \mathrm{A}$ & 0.05 \\
Water/binder & W/B & 6 \\
Water/aggregate & W/A & 0.30
\end{tabular}

lead and zinc sulphides in limestone gangue. The principle characteristics of the waste are shown in Table 1. On the bedrock schistose permeability tests were performed in situ which provided the value of $2.2 \times 10^{-8} \mathrm{~m} / \mathrm{s}$.

The mining waste was characterized by mineral, physical and chemical analysis as reported in previous studies (Desogus et al. 2012a, b, c). The material has a predominantly carbonate matrix: calcite $\left(\mathrm{CaCO}_{3}\right)$, dolomite $\left(\mathrm{CaMg}\left(\mathrm{CO}_{3}\right)_{2}\right)$ and, subordinately quartz $\left(\mathrm{SiO}_{2}\right)$. More than $55 \%$ of the material is smaller than $38 \mu \mathrm{m}$. Table 2 and Table 3 (Desogus et al. 2012a) show the major and minor chemical components; the first column of Table 3 show the threshold limit values of contamination. Table 3 highlights high concentrations of $\mathrm{Zn}, \mathrm{Cd}$ and $\mathrm{Pb}$.

\section{The backfill}

The use of cemented filled with tailings is a practice well known mining (Thomas et al. 1979; Belem et al. 2000, 2004, Batchelor 2006). The Table 4 summarized the link between mechanical characteristics (strength and deformability) and content of Binder (Portland cement). The ratio binder/aggregate generally used in the cemented backfill for Overcut Mining Methods is variable between $5 \%$ and $10 \%$. A possible composition of the mix is represented in the Table 5 .

The mentioned features are applicable to the case of a still active mine. However, in the case of an abandoned mine such a solution involves high costs, for the use of the Portland cement, the risk of pollution, for the leaching of heavy metals by the tailings, the delay in the solidification, due to the curing time. For these reasons, in the case of filling of an abandoned mine, the solution of geochemical 
Table 6 Stabilization tests (concentrations are in $\mathrm{mg} / \mathrm{L}$ ) using potassium dihydrogen phosphate

\begin{tabular}{llllll}
\hline Test & $\mathrm{MW}$ & 1 & 2 & 3 & 4 \\
\hline $\mathrm{KH}_{2} \mathrm{PO}_{4}(\%)$ & 0 & 0.5 & 1 & 2 & 4 \\
$\mathrm{pH}$ & 8 & 6.9 & 6.6 & 6.3 & 5.8 \\
$\mathrm{As}$ & $<0.001$ & 0.019 & 0.025 & 0.025 & 0.026 \\
$\mathrm{Cd}$ & 0.0017 & $<0.0005$ & $<0.0005$ & 0.006 & 0.009 \\
$\mathrm{Cu}$ & $<0.005$ & $<0.005$ & $<0.005$ & $<0.005$ & $<0.005$ \\
$\mathrm{Fe}$ & $<0.01$ & $<0.01$ & $<0.01$ & $<0.01$ & 0.13 \\
$\mathrm{Ni}$ & 0.006 & 0.008 & 0.009 & 0.001 & 0.025 \\
$\mathrm{~Pb}$ & 0.103 & 0.022 & 0.008 & 0.011 & 0.067 \\
$\mathrm{Zn}$ & 382 & 43 & 97 & 189 & 566 \\
$\mathrm{P}$ & $<0.08$ & 63.6 & 167 & 259 & 445 \\
\hline
\end{tabular}

problem requires the use of a mix composition already inert at the time of its installation, and not only after solidification of the casting.

The most critical phase of the operation of backfill is to be transporting of the mixture. Transport and storage of the mixtures is usually by pumping, with operating pressures in the range 1-5 MPa, depending on the flow regime of the sludge and of the chemical-physical characteristics of the mix (AUA 2010).

With regard to the characteristics of the backfill pumping, sandfill with cementitious additions is transported as a suspension at about $70 \%$ solids (i.e. weight of solid/total weight of mix). Flow velocities exceeding about $2 \mathrm{~m} / \mathrm{s}$ are required to maintain homogeneous dispersion of the fill components in the slurry. The conditions of pumpability vary with the particle size composition of the solid on which plays an important role the cement content.

It is therefore important to investigate the effects from the geochemical point of view of different mixtures in which varies the ratio of water/solid, for replacement of the solid with the binder and therefore keeping constant the water/binder ratio. This condition should also ensure strength values substantially constant. The variation range of water/solid considered is $25 \%-50 \%$ and the value of water/binder ratio is 5 .

\section{Laboratory tests}

Preliminary assessment of a cement-based stabilization/ solidification treatment of mine tailings using natural and artificial additives has been discussed in Desogus et al. (2012b). Stabilization-solidification treatment of mine tailings using Portland cement, potassium dihydrogen phosphate and ferric chloride hexahydrate has been presented in Desogus et al. (2013). The results obtained are briefly summarized below (optimal ratio of additives).
Table 7 Leaching tests on the mixture inert, Portland cement and additives

\begin{tabular}{lcc}
\hline $\mathrm{KH}_{2} \mathrm{PO}_{4}(\%)$ & 0 & 1 \\
$\mathrm{FeCl}_{3}(\%)$ & 0 & 1 \\
$\mathrm{C} 32(\%)$ & 0 & 5 \\
$\mathrm{pH}$ & 8.2 & 10.9 \\
$\mathrm{As}(\mathrm{mg} / \mathrm{L})$ & $<0.001$ & 0.003 \\
$\mathrm{Cd}(\mathrm{mg} / \mathrm{L})$ & $<0.0005$ & $<0.001$ \\
$\mathrm{Cu}(\mathrm{mg} / \mathrm{L})$ & $<0.005$ & $<0.010$ \\
$\mathrm{Fe}(\mathrm{mg} / \mathrm{L})$ & 0.229 & 0.017 \\
$\mathrm{Mn}(\mathrm{mg} / \mathrm{L})$ & 0.061 & $<0.005$ \\
$\mathrm{~Pb}(\mathrm{mg} / \mathrm{L})$ & 0.103 & 0.007 \\
$\mathrm{Sb}(\mathrm{mg} / \mathrm{L})$ & $<0.0005$ & $<0.0005$ \\
$\mathrm{Zn}(\mathrm{mg} / \mathrm{L})$ & 0.376 & 0.021 \\
$\mathrm{P}(\mathrm{mg} / \mathrm{L})$ & & 0.03 \\
\hline
\end{tabular}

In the second phase of the study it was investigated if the change of the water/solid, obtained for the purpose of keeping constant resistance the water/binder ratio, it retains the ability to inhibit the solubility of zinc and lead.

\subsection{Optimal ratio of additives}

A previous investigation (Desogus et al. 2012c) identified a number of binder/additive mixtures that can reduce the heavy metal release by the tailings (Mulligan et al. 2001; Desogus et al. 2012c). The study shows the influence on the release of contaminants $(\mathrm{Pb}, \mathrm{Zn}, \mathrm{Cd}$, etc.) from wastes and in combination with binders and additives, keeping constant and equal to 5 the water/binder ratio.

Solidification tests show that mixtures with $5 \%$ of Portland cement $\mathrm{C} 32.5$ and $1 \% \mathrm{KH}_{2} \mathrm{PO}_{4}$ and $\mathrm{FeCl}_{3}$, allow fulfilling the regulatory requirements for groundwater. Cement, used without additives, does not give rise to acceptable efficiencies, also with very high contents of this component. The results are shown on Table 6 .

The chemical analyzes performed by ICP-OES (PerkinElmer Optima 7000 DV) have shown, see Table 3, high concentrations of $\mathrm{Cd}(56.2 \mathrm{mg} / \mathrm{kg}), \mathrm{Pb}(2,354 \mathrm{mg} / \mathrm{kg})$ and $\mathrm{Zn}(7,860 \mathrm{mg} / \mathrm{kg})$. The eluates of the leaching tests (see Table 7), carried out according to UNI 10802 UNI (2005), submit content of $\mathrm{Pb}(0.103 \mathrm{mg} / \mathrm{L})$ concentrations that exceed the threshold for groundwater contamination $(\mathrm{Pb}=0.01 \mathrm{mg} / \mathrm{L}-\mathrm{Dls}$ 152/2006), considered as reference limits during the study.

The distribution of contaminants in the different size fractions has been also investigated. The results shown that $\mathrm{Pb}$ is concentrated mainly in the finer classes (about $40 \%$ of the $\mathrm{Pb}$ is in the classes below $53 \mu \mathrm{m}$ ) whereas for the elements $\mathrm{Zn}$ and $\mathrm{Cd}$ is observed a significant decrease in 
Table 8 Components of the mixture by weight $(\mathrm{g})$

\begin{tabular}{lllll}
\hline ID Sample & M1 & M2 & M3 & M4 \\
\hline Solid & 2,000 & 2,000 & 2,000 & 2,000 \\
Aggregate & 1,900 & 1,875 & 1,850 & 1,800 \\
Binder & 100 & 125 & 150 & 200 \\
$\mathrm{KH}_{2} \mathrm{PO}_{4}$ & 20 & 20 & 20 & 20 \\
$\mathrm{FeCl}_{3}$ & 20 & 20 & 20 & 20 \\
$\mathrm{~W}$ & 500 & 625 & 750 & 1,000 \\
$\mathrm{~W} / \mathrm{B}$ & 5 & 5 & 5 & 5 \\
$\mathrm{~B} / \mathrm{S}$ & 0.05 & 0.0625 & 0.075 & 0.1 \\
$\mathrm{~W} / \mathrm{S}$ & 0.25 & 0.31 & 0.38 & 0.5 \\
\hline
\end{tabular}

Table 9 Results of strength tests

\begin{tabular}{|c|c|c|c|}
\hline Binder/Solid (\%) & Strength $(\mathrm{kPa})$ & Average $(\mathrm{kPa})$ & SD \\
\hline \multirow[t]{5}{*}{5.00} & 336 & 357 & 47 \\
\hline & 424 & & \\
\hline & 389 & & \\
\hline & 318 & & \\
\hline & 318 & & \\
\hline \multirow[t]{5}{*}{6.25} & 141 & 195 & 35 \\
\hline & 212 & & \\
\hline & 177 & & \\
\hline & 212 & & \\
\hline & 230 & & \\
\hline \multirow[t]{5}{*}{7.50} & 265 & 252 & 9 \\
\hline & 248 & & \\
\hline & 248 & & \\
\hline & 248 & & \\
\hline & - & & \\
\hline \multirow[t]{5}{*}{10.00} & 513 & 400 & 104 \\
\hline & 477 & & \\
\hline & 371 & & \\
\hline & 248 & & \\
\hline & 389 & & \\
\hline
\end{tabular}

the concentrations particle size classes between 38 and 10 microns. According to Italian low (Dls 152/2006 and DM 27/09/2010), the waste is classified as non-hazardous special waste.

The results of inerting the top were obtained with a mixture composed of (by weight) by a hydraulic binder (cement pozzolanic EN 197-1- CEM IV/B 32.5 R), 5 \%; an additive stabilization (phosphate monobasic potassium $\mathrm{KH}_{2} \mathrm{PO}_{4}$ ) (Ruby et al. 1994), $1 \%$, and an additive optimization (ferric chloride hexahydrate $\mathrm{FeCl}_{3} 6 \mathrm{H}_{2} \mathrm{O}$ ) (Behrang and Jacimaria 2011), $1 \%$. See comparison of Table 7.

The combined use of potassium dihydrogen phosphate and ferric chloride hexahydrate allows to reduce the mobility of the $\mathrm{Pb}$ through the formation of $\left(\mathrm{Pb}_{5}\left(\mathrm{PO}_{4}\right)_{3} \mathrm{Cl}\right)$, compounds of $\mathrm{Pb}$ highly stable in wide ranges of $\mathrm{pH}$ and Eh ranges (Miretzky and Fernandez-Cirelli 2007; Ryan et al. 2001; Berti and Cunningham 1997). Moreover, the use of the two additives allows solving the issue of arsenic in solution determined by the use of only phosphate. The results have proved satisfactory, both in the mixture on both monolithic samples after solidification, crushing and leaching tests.

\subsection{Effect of water/solid ratio variability}

The research was conducted by varying the ratio solid/ cement $(5 \%, 6.25 \%, 7.5 \%, 10 \%)$ while maintaining a constant water-cement ratio constant equal to $1: 5$; the additives accounted the $1 \%$ of the solid (i.e. Aggregate + Portland Cement).

\subsubsection{Preparation of samples and strength tests}

The mixture was placed in cylindrical sample holder. They are packed 20 monolithic samples (size: $6.1 \mathrm{~cm}$ in diameter and $12 \mathrm{~cm}$ high) divided into four categories (M1, M2, M3, M4), see Table 8.

Tests were prepared according to the following method:

- mixing of components using electric mixer;

- placing of the mixture in plastic cylindrical sample holder;

- aging of the sample in a climate chamber (temperature $20{ }^{\circ} \mathrm{C}$ and humidity $>95 \%$ ) for a period of 28 days.

Table 10 Results of analysis of multiple range test at $99 \%$ Confidence Limit

\begin{tabular}{llllll}
\hline Mix & Count & Mean & \multicolumn{2}{l}{ Homogeneous groups } & \\
\hline C6_25 & 5 & 195 & $\mathrm{X}$ & & \\
C7_5 & 4 & 252 & $\mathrm{X}$ & $\mathrm{X}$ & \\
C5 & 5 & 357 & & $\mathrm{X}$ & $\mathrm{X}$ \\
C10 & 5 & 400 & & & $\mathrm{X}$ \\
\hline
\end{tabular}

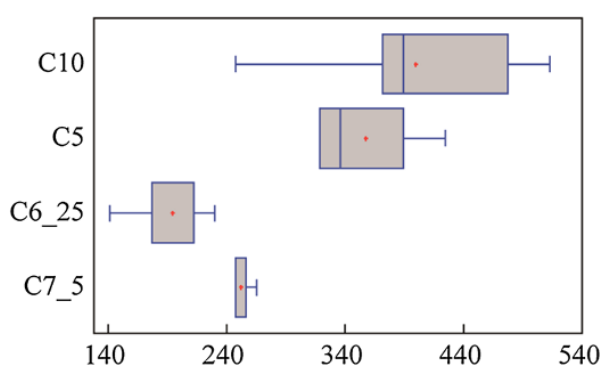

Fig. 3 Graphical statistical analysis by box and whisker plot of results of strength $(\mathrm{kPa})$ tests 


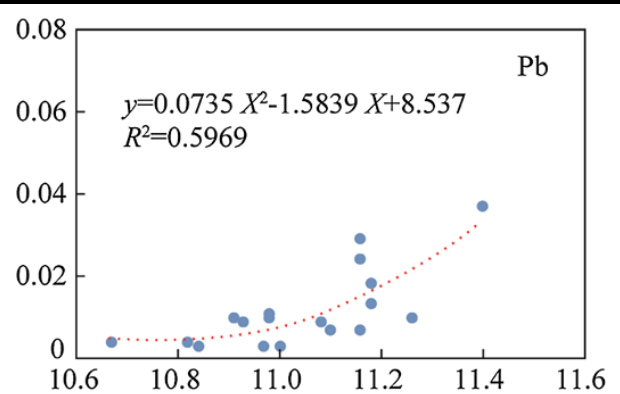

Fig. 4 Results of leaching tests: concentrations of $\mathrm{Pb}$ measured as a function of $\mathrm{pH}$

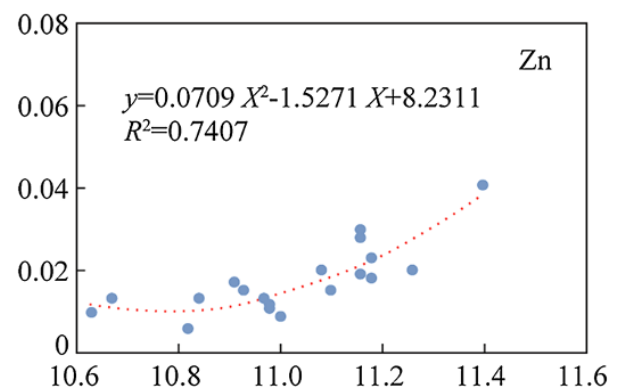

Fig. 5 Results of leaching tests: concentrations of $\mathrm{Zn}$ measured as a function of $\mathrm{pH}$

After the aging period, samples were taken from the climate chamber. All tests, done in five samples, were prepared using the components as indicated in Table 8 .
In the tests was considered the addition of $1 \%$ of additives $\left(\mathrm{KH}_{2} \mathrm{PO}_{4}\right.$ and $\left.\mathrm{FeCl}_{3}\right)$ that represents the optimal quantity detected by the stabilization tests.

Exceeded 28 days (as established by UNI 1082 UNI (2005), samples were taken from the room thermostat and tested in uniaxial compression. The strength tests were performed following the IRSM suggested methods.

The results of strength tests are shown on Table 9.

\subsubsection{Leaching tests}

The leaching tests were performed on the same samples previously subjected to simple compression and then broken. To run the test applies to Appendix A of the UNI 10802 UNI (2005), according to the method prescribed by the standard UNI EN 12457-2 UNI (2004).

After the simple compression test, the samples were crushed, screened to $4 \mathrm{~mm}$ and dried in an oven at a temperature of $20^{\circ} \mathrm{Cfor}$ a time of $24 \mathrm{~h}$ (UNI EN 10802) and, finally, tested for elution.

The test provides that mixtures be used with a ratio liquid/solid (L/S) of $10(50 \mathrm{~g}$ of solid and $500 \mathrm{~mL}$ of distilled water). The components of the mixture were placed inside a beaker glass, with a capacity of $1,000 \mathrm{~mL}$. The mixture was stirred at a constant speed of $100 \mathrm{rpm}$, for $24 \mathrm{~h}$, using a stirring device vane.

After $24 \mathrm{~h}$ of stirring, the suspension was decanted for $15 \mathrm{~min}$ and filtered with a membrane filter $(0.45 \mu \mathrm{m})$. The

Table 11 Results of leaching tests, mg/L

\begin{tabular}{|c|c|c|c|c|c|c|c|c|}
\hline ID & A $\%$ & B \% & W \% & $\mathrm{pH}$ & $\mathrm{Cu}$ & $\mathrm{Fe}$ & $\mathrm{Pb}$ & $\mathrm{Zn}$ \\
\hline \multirow[t]{5}{*}{ M1 } & 95 & 5 & 25.0 & 10.6 & 0.013 & 0.032 & 0.004 & 0.01 \\
\hline & 95 & 5 & 25.0 & 10.7 & 0.013 & 0.033 & 0.004 & 0.013 \\
\hline & 95 & 5 & 25.0 & 10.8 & 0.012 & 0.031 & 0.003 & 0.013 \\
\hline & 95 & 5 & 25.0 & 10.9 & 0.013 & 0.033 & 0.010 & 0.017 \\
\hline & 95 & 5 & 25.0 & 10.9 & 0.015 & 0.034 & 0.009 & 0.015 \\
\hline \multirow[t]{5}{*}{$\mathrm{M} 2 \mathrm{C}$} & 93.75 & 6.25 & 31.3 & 11.0 & 0.01 & 0.041 & 0.003 & 0.013 \\
\hline & 93.75 & 6.25 & 31.3 & 11.0 & 0.009 & 0.037 & 0.010 & 0.011 \\
\hline & 93.75 & 6.25 & 31.3 & 11.0 & 0.011 & 0.037 & 0.011 & 0.012 \\
\hline & 93.75 & 6.25 & 31.3 & 11.2 & 0.014 & 0.033 & 0.029 & 0.03 \\
\hline & 93.75 & 6.25 & 31.3 & 11.2 & 0.015 & 0.035 & 0.024 & 0.028 \\
\hline \multirow[t]{4}{*}{ M3A } & 92.5 & 7.5 & 37.5 & 11.1 & 0.012 & $<0.055$ & 0.009 & 0.02 \\
\hline & 92.5 & 7.5 & 37.5 & 11.2 & 0.013 & $<0.05$ & 0.013 & 0.018 \\
\hline & 92.5 & 7.5 & 37.5 & 11.2 & 0.011 & $<0.051$ & 0.018 & 0.023 \\
\hline & 92.5 & 7.5 & 37.5 & 11.4 & 0.014 & $<0.056$ & 0.037 & 0.041 \\
\hline \multirow[t]{5}{*}{ M4 } & 90 & 10 & 50.0 & 10.8 & 0.01 & 0.044 & 0.004 & 0.006 \\
\hline & 90 & 10 & 50.0 & 11.0 & 0.01 & 0.044 & 0.003 & 0.009 \\
\hline & 90 & 10 & 50.0 & 11.1 & 0.012 & 0.064 & 0.007 & 0.015 \\
\hline & 90 & 10 & 50.0 & 11.2 & 0.012 & 0.081 & 0.007 & 0.019 \\
\hline & 90 & 10 & 50.0 & 11.3 & 0.011 & 0.075 & 0.010 & 0.02 \\
\hline
\end{tabular}


sample thus prepared was used for the $\mathrm{pH}$ measurement and chemical analysis by ICP MS.

The results of leaching tests are shown on Table 10.

\subsubsection{Results and discussion}

The results of the experimental tests, strength and leaching, are shown in the following Tables (9 and 10) and Figs. (3, 4 and 5).

The strength results obtained are in agreement with those that presents the international literature for equal aging and water/binder ratio. The statistical method used to discriminate among the means is Fisher's Least Significant Difference (LSD) procedure. The results showed that there is a significant difference between the two groups of strengths obtained for concentrations binder/solid equal to 5 (C5) and 10 (C10) and equal to 6.25 (C6_25) and 7.5 (C7_5). While significant differences exist for all other combinations, as well as showing the Table 10.

However, despite this result is observed minor differences (in the range 200-400 kPa), so we can say that strength values do not undergo important variations even if statistically significant.

Table 11 shows the results of leaching tests. The values of $\mathrm{KH}_{2} \mathrm{PO}_{4}$ and $\mathrm{FeCl}_{3}$ ) are constant (equal to $1 \%$ ) as well as As $(<0.001), \mathrm{Cd}(<0.0005), \mathrm{Mn}(<0.005)$ and $\mathrm{P}(<0.05)$. The regressions analysis of Figs. 4 and 5 show the effects of $\mathrm{pH}$ changes against leaching of $\mathrm{Pb}$ and $\mathrm{Zn}$ respectively. The lead in some samples exceeds the threshold value of contamination, while the other analytes are always below the threshold value.

The increasing the cement content also increases the hydrated lime $\left(\mathrm{Ca}(\mathrm{OH})_{2}\right)$; since the $\mathrm{OH}$-ions increases the $\mathrm{pH}$ becomes basic (alkaline environment). The alkaline conditions give rise to a strong increase in sales of contaminants that enter in a field of high solubility.

Although the data show quite dispersed, the correlation coefficients are not particularly high; developments respect the classical parabolic relationship (vertical axis) of these experimental relations. The lower solubility values for both correspond to a value of $\mathrm{pH}$ equal to 10.75 .

The thresholds of contamination according to the Italian regulation are for $\mathrm{Zn}=3,000 \mu \mathrm{g} / \mathrm{L}$ and for $\mathrm{Pb}=10 \mu \mathrm{g} / \mathrm{L}$. The measured values for $\mathrm{Zn}$ are well below the limit, while the $\mathrm{Pb}$ changes from values lower than the limit up to ten times the limit. Therefore, it is particularly important to identify a range of $\mathrm{pH}$ optimum and the corresponding ratio binder/solid.

\section{Conclusions}

The paper discusses the problem of defining the composition of a cemented backfill (with flotation tailings) in a non- traditional field of application and with a dual purpose. The field is the filling of an abandoned mine affected by subsidence. The two aims are represented by stabilization of mine voids and by the rehabilitation the area occupied by tailings basins.

The traditional mining application (cut and fill methods) requires a backfill of particular strength and pumpability. While, in the proposed application the main properties are the not pollution of the groundwater (by leaching of heavy metals) and the pumpability, being the strength less important.

The solution found is referred to a tailings characterized by a carbonate matrix and a not negligible fraction of sulphides of $\mathrm{Pb}$ and $\mathrm{Zn}$ residues. The results obtained showed that:

(1) The presence of additives $\left(\mathrm{KH}_{2} \mathrm{PO}_{4}\right.$ and $\left.\mathrm{FeCl}_{3}\right)$, in the proportion of $1 \%$ by weight, ensures the control of the $\mathrm{Pb}$ concentration in the eluates within the limits prescribed by law.

(2) The components of the mixture must be in the following proportions:

- the ratio binder/solid must be in the range 5\%-6\%;

- the ratio water/solid must be in the range 25\%-30\%;

- the ratio water/binder should be 5 .

Open Access This article is distributed under the terms of the Creative Commons Attribution License which permits any use, distribution, and reproduction in any medium, provided the original author(s) and the source are credited.

\section{References}

AUA, Raymond W. Henn (eds) (2010) Guidelines for Backfilling and Contact routing of Tunnels and Shafts ASCE Press, Reston

Batchelor B (2006) Overview of waste stabilization with cement. Waste Manag 26:689-698

Behrang P, Jacimaria R (2011) Surface complexation modeling of the removal of arsenic from ion-exchange waste brines with ferric chloride. J Hazard Mater 188:399-407

Belem T, Benzaazoua M (2004) An overview on the use of paste backfill technology as a ground support method in cut-and-fill mines.in: Villaescusa, Potvin (eds) Proc. of the 5th Int. Symp. on Ground support in Mining and Underground Construction, Perth, 28-30 September 2004, Perth, Tayler \& Francis Group, London, pp 637-650

Belem T, Benzaazoua M, Bussière B (2000) Mechanical behavior of cemented paste backfill. In: 53rd annual conference of the Canadian geotechnical society, vol. 1, Monteral, 2000

Berti W, Cunningham S (1997) In-place inactivation of $\mathrm{Pb}$ in $\mathrm{Pb}$ contaminated soils. Environ Sci Technol 31:1359-1364

Costa M, Manca PP and Putzolu S (1998) Discontinuous subsidence analysis by numerical modelling in Acquaresi Mine, Sardinia, Italy. In MPES, Balkema, Rotterdam, pp 309-314

Desogus P, Manca PP, Orrù G (2012a) Heavy metal leaching contaminated soils from a metallurgical plant, International Journal of Mining, Reclamation and Environment. (In press, doi: $10.1080 / 17480930.2012 .708221$ ) 
Desogus P, Manca PP, Orrù G (2012b) Preliminary assessment of a cement-based stabilization/solidification treatment of mine tailings using natural and artificial additives, Proc.21st Int. Symp MPES 2012, ISSN 21673322.

Desogus P, Manca PP, Orrù G (2012c) Treatment of mine tailings. Rifiuti Solidi 5:295-309

Desogus P, Manca PP, Orrù G, Zucca A (2013) Stabilizationsolidification treatment of mine tailings using portland cement, potassium dihydrogen phosphate and ferric chloride hexahydrate. Miner Eng 45:47-54

EPA (1980) Control and Treatment Technology for the Metal Finishing Industry, Sulfide Precipitation. EPA 625/8-80-003

Fall M, Benzaazoua M (2003) Advances in predicting performance properties and cost of paste backfill.in:Tailings and Mine Waste, pp 73-85

Grosso B, Manca PP (2009) "La Subsidenza nelle coltivazioni sub level stoping: il caso della miniera di Acquaresi (Sardegna)", Geam. vol.2, pp 37-44, ISSN: 1121-9041

Miretzky P, Fernandez-Cirelli A (2007) Phosphates for Pb immobilization in soil: a review. Environ Chem Lett 6(3):121-136

Mulligan CN, Yong RN, Gibbs BF (2001) Remediation technologies for metal-contaminated soils and groundwater: an evaluation. Eng Geol 60(1-4):193-207
Ruby MV, Davis A, Nicholson A (1994) In situ formation of lead phosphates in soil as a method to immobilize lead. Environ Sci Technol 28:646-654

Ryan K, Zhang P, Hesterberg D, Chou J, Sayers D (2001) Formation of chloropyromorphite in lead-contaminated soil amended with hydroxyapatite. Environ Sci Technol 35:3798-3803

Scheckel KG, Ryan JA (2002) Effects of aging and pH on dissolution kinetics and stability of chloropyromorphite. Environ Sci Technol 36:2198-2204

Scheckel KG, Ryan JA (2004) Spectroscopic speciation and quantification of lead in soil. J Environ Qual 33:1288-1295

Thomas EG, Nantel LH, Notley KR (1979) Fill technologies in underground metalliferous mines. Academic.Services, Kingston

UNI (2004) UNI EN 12457-2. Caratterizzazione dei rifiuti Lisciviazione-Prova di conformità per la lisciviazione di rifiuti granulari e di fanghi - Parte 2: Prova a singolo stadio, con un rapporto liquido/solido di $10 \mathrm{l} / \mathrm{kg}$, per materiali con particelle di dimensioni minori di $4 \mathrm{~mm}$ (con o senza riduzione delle dimensioni)

UNI (2005) UNI 10802. Rifiuti - Rifiuti liquidi, granulari, pastosi e fanghi-Campionamento manuale e preparazione ed analisi degli eluati, $77-81$ 